The International Master Program in Biomedical Sciences (IMBS) is a joint program between Universidad de Buenos Aires in Argentina (Faculty of Pharmacy and Biochemistry and Faculty of Medicine) and Albert-Ludwigs University of Freiburg in Germany. It is supported by the DAAD (German Federal Institution for Academic Exchange) and private philantropy. The aim of this program is to provide scientific knowledge and state-of-the-art experience to current and emerging biomedical research areas with a focus on translational research and development.

The IMBS lasts two years and it is held in English. The academic year starts in February. The first 7 months are carried out at Universidad de Buenos Aires. The following 5 months take place in Freiburg including intensives courses, special lectures and laboratory practice. Upon successful completion of the module courses in Buenos Aires and in Freiburg, the students will receive a Diploma of Advanced Studies (DAS) of each University. The last twelve months are dedicated to the Master Thesis Research which can be done either in Buenos Aires or in Freiburg. The students then defend their thesis and are awarded with the Degree Master of Science of Universidad de Buenos Aires and Degree of Advanced Studies (DAS) of Albert-Ludwigs University of Freiburg. Good to excellent results after the first year qualify for admission to a three-year doctoral project in one of the participating research groups. The program is open to students from all over the world who hold a four-year Bachelor's degree (or equivalent degree) in biosciences, biochemistry, biology, medicine, or related fields. Admission is only possible to the first segment of the program, not directly to the PhD program

\section{Schedule of Events}

Application deadline: October

Annual International Congress November

in Translational Medicine:

Master Thesis Defense: November

Classes in Buenos Aires: February-September (first year)

Classes in Freiburg: September-February

Thesis Research in February-November Thesis Research in February-Nover
Buenos Aires or Freiburg: (second year)

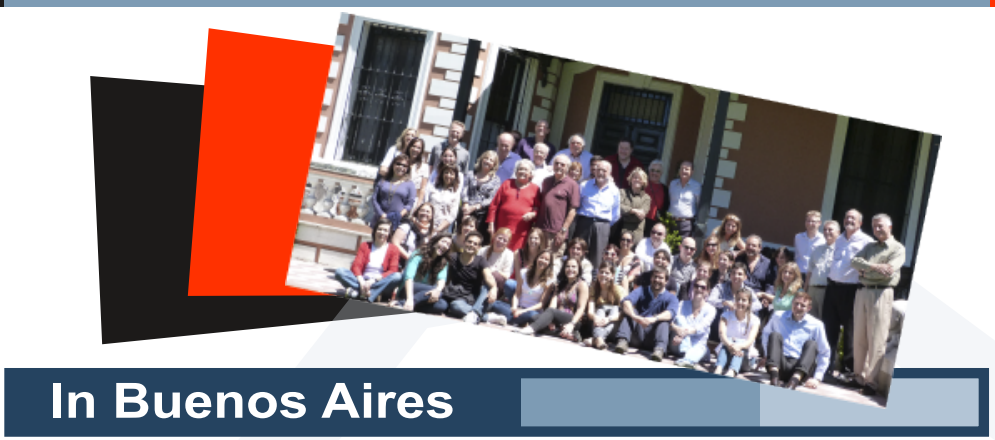

Module I: Biological Oxidations and Bioenergetics Module II: Biochemistry and Molecular Biology Module III: Physiology, Pharmacology and Toxicology Module IV: Microbiology, Virology and Immunology

Module V: Neurobiology

Module VI: Cellular and Molecular Pathology

Module VII: Clinical Medicine

Module VII: Molecular Oncology

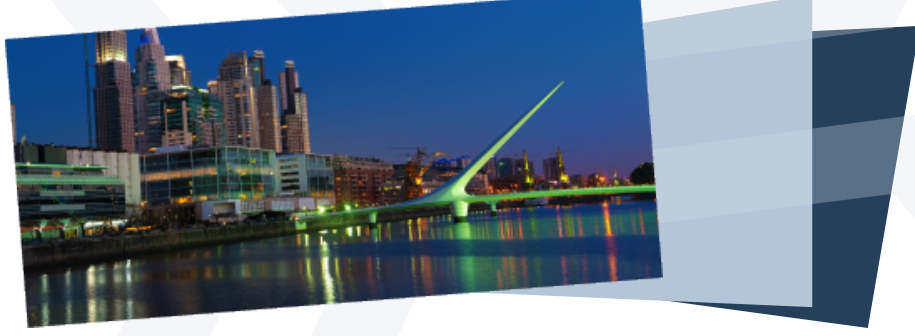

\section{In Freiburg}

Module IX: Methodology workshops. Seminars and Conferences.

1 - Molecular \& Cellular Biology

2 - Immunology and Pathology

3a - Pharmacology \& Toxicology

3b - Molecular Cardiology

3c - Molecular Oncology

$3 d$ - Genetics of Disease and Cancer

$4 a$ - Materials \& Microsystems for Life Sciences

$4 \mathrm{~b}$ - Biostatistics

$4 \mathrm{c}$ - Bioethics

5 - Laboratory Research 1 \& 2

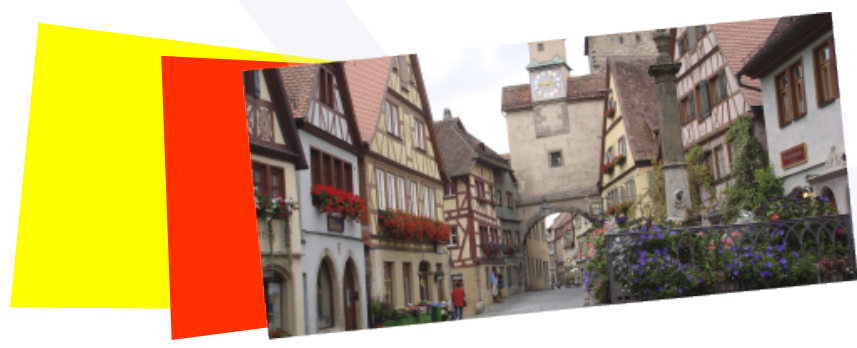

Freiburg is one of the most popular cities in Germany. It is located on the slopes of the Black Forest and is the sunniest city in Germany. Freiburg is a famous center of academics and research. As one of the oldest universities in Germany, the Albert-Ludwigs University of Freiburg (ALU) celebrated its 550 year anniversary in 2007 and is one of Germany's most prestigious and leading research as well as teaching institution in Europe.

The University Medical Center Freiburg enjoys an excellent international reputation due to world-class medical treatment and extensive clinical research.

\section{Buenos Aires}

Buenos Aires is the capital of Argentina, the country's largest city and the third largest city in Latin America. Located on the shores of Río de la Plata, Buenos Aires has always been an open-hearted city. It is a modern, dynamic and radiant city which features the European architecture of its founder. Buenos Aires enjoys a perennial mild climate. It has an intense cultural life where tango, coffee klatches and football (soccer) are essential in its people's daily life. The University of Buenos Aires (UBA) was founded in 1821. At present, it represents a well-known and prestigious institution for the training of professionals with over 6650 teachers and more than 100.800 students divided into 13 faculties. Within the fields of science and technology, the University of Buenos Aires has an outstanding structure made up of around 6000 researchers and scholars and over 1500 ongoing research projects financed by the University, the National Agency of Science and Technology, the CONICET, and other organizations.

The exchange of foreign researchers, teachers and students and the design of projects of common interests are some of UBA's main aims. 


\section{Contact and Application}

If you are interested in the IMBS, go to our websites: www.biomedmaster.org

www.ffyb.uba.ar

or scan the QR code to check out

our Information Booklet:

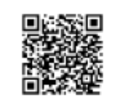

or scan the QR code to access the

Application Form:

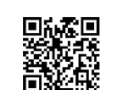

or contact us at:

Universidad de Buenos Aires

Miss. María Esquiroz

Facultad de Farmacia y Bioquímica

Junín 956 - Planta Principal

Ciudad Autónoma de Buenos Aires

C1113AAD, Argentina

e-mail: imbs@ffyb.uba.ar

phone: (+54 11) 52874920

www.ffyb.uba.ar

Albert-Ludwigs University of Freiburg

Bärbel Schätzle, Dipl. Soz. Päd.

Project Coordinator International Master Program in Biomedical

Sciences

Institute of Molecular Medicine and Cell Research, AG Borner Stefan-Meier-Str. 17/ 79104 Freiburg, Germany

phone: +49 761/203-97489

e-mail: imbs@mol-med.uni-freiburg.de

www.biomedmaster.org

Supported by:
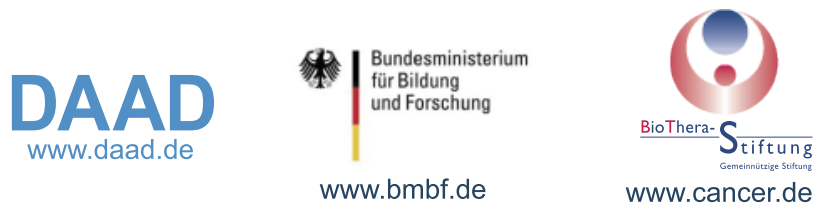

Freiburg:

Prof. Dr. Christoph Borner

Program Director Freiburg

christoph.borner@uniklinik-freiburg.de

Prof. em. Dr. Drs. h.c. Roland Mertelsmann

Program Co-director Freiburg

roland.mertelsmann@uniklinik-freiburg.de

Bärbel Schätzle

IMBS Project Coordinator

imbs@mol-med.uni-freiburg.de

Buenos Aires:

Prof. Cristina Arranz

Program Director Buenos Aires

carranz@ffyb.uba.ar

Prof. Dr. Ricardo Gelpi

Program Co-director Buenos Aires

rgelpi@fmed.uba.ar

Prof. Dr. Marta Mollerach

IMBS Committee Buenos Aires

mmollera@ffyb.uba.ar

Prof. Dr. Daniel Turyn

IMBS Committee Buenos Aires

dturyn@qb.ffyb.uba.ar

Prof. Dr. De Nicola

IMBS Committee Buenos Aires

denicola@dna.uba.ar

María Esquiroz

IMBS Secretary

imbs@ffyb.uba.ar

\section{INFORMATION}

A joint program of the

Albert-Ludwigs-University of Freiburg (Germany) and Universidad de Buenos Aires (Argentina)

MSc

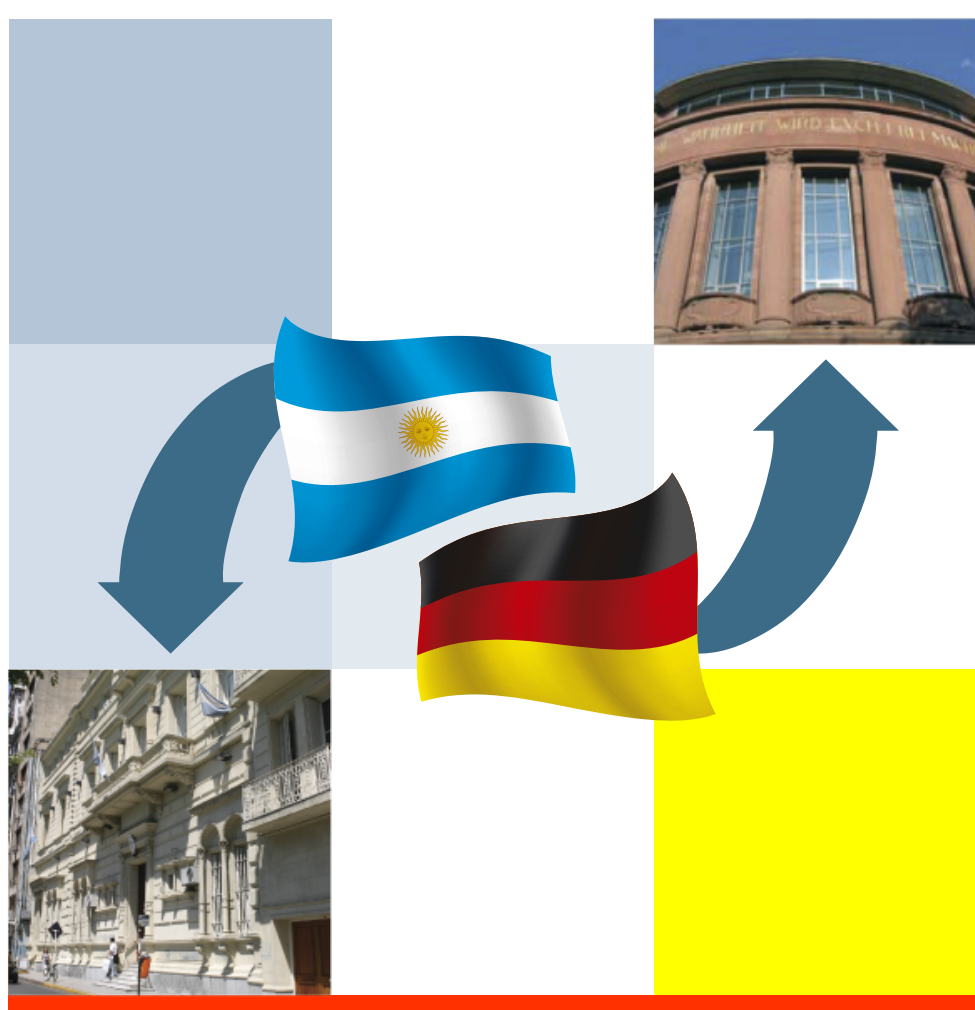

